\title{
Herd Behavior of Investors and Default Risks of P2P Online Lending*
}

\author{
Junghoon Seon*, Professor, Konkuk University \\ Sukman Han, Ph.D, Konkuk University
}

\begin{abstract}
$<$ Abstract $>$
We examine the impact of investors' herding on the default risk of $\mathrm{P} 2 \mathrm{P}$ online loans. More specifically, we first decompose the number of investors in each loan into two components: the component caused by public information and the component reflecting factors other than public information. Then we investigate the effect of each component on the default risk of loans, using an ordered probit analysis. We use the data on 3,720 loans that were traded through 8percent, a Korean price-posted P2P platform from February 2015 to December 2017. We find the results as follows: First, the number of investors is determined by information that are provided by the platform and macro-economic variables (hereafter public information). Second, the number of investors explained by public information decreases the default risk of the loans. However, the number of investors reflecting factors other than public information increases the default risk of the loans. These results are interpreted as an evidence supporting 'herding' hypothesis: Investors follow intentionally other investors' investment decision. These results suggest that the quantity increasement and quality improvement of public information provided by a P2P platform can improve the efficiency of P2P lending market reducing herding caused by factors other than public information.
\end{abstract}

Keywords: P2P Lending; Default Risk; Herding; Posted-prices System; Auctions System JEL Classification: G21, G23

* Corresponding Author. Address: School of Business Konkuk University, 120, Neungdong-ro, Gwangjin-gu, Seoul, Korea, 05029; E-mail: jhseon@konkuk.ac.kr; Tel: +82-2-450-4099.

Received: February 28, 2021; Revised: April 12, 2021; Accepted: April 16, 2021 


\title{
투자자의 군집행동과 $\mathrm{P} 2 \mathrm{P}$ 온라인 대출의 채무불이행 위험
}

\author{
선 정 훈 (건국대학교 교수)* \\ 한 석 만 (건국대학교 박사)
}

\begin{abstract}
이 논문은 $\mathrm{P} 2 \mathrm{P}$ 온라인 대출시장에서 투자자의 군집행동이 대출의 채무불이행 위험에 미치는 영향을 규명하는 것을 목적으로 한다. 이를 위해 먼저 회귀분석을 통해 각 대출의 전체 투자자 수를 플랫폼에서 제공되는 투자정보와 자금 모집 당시에 공표되는 거시경제지표(이하 공적 정보)에 의한 부분과 기타 요인에 의한 부분으로 파악한다. 이어 각 부분이 상환 성공, 연체 및 부도의 채무불이행 정도에 미치는 영향을 순위 프로빗 분석을 통해 분석한다. 한국의 가격 게시형(price-posted) P2P대출 플랫폼인 에잇퍼 센트에서 2015년 2월부터 2017년 12월까지 이루어진 3,720건의 대출에 대한 2018년 10월 기준 자료를 이용한 분석 결과는 다음과 같다. 첫째, 대출 당 투자자 수가 공적 정보의 영향을 받는다. 둘째, 공적 정보 반영 투자자 수의 증가는 채무불이행 위험을 감소시킨다. 하지만 기타 요인에 의한 투자자 수의 증가는 대출의 채무불이행 위험을 높인다. 이러한 결과는 공적 정보 이외의 요인에 의한 투자자의 군집행동 발생 가능성을 시사한다. 이에 $\mathrm{P} 2 \mathrm{P}$ 대출 플랫폼에서 제공되는 공적 정보의 양과 질을 개선함 으로써 공적 정보 이외 요인으로 인해 발생하는 투자자의 군집행동을 줄이고 $\mathrm{P} 2 \mathrm{P}$ 온라인 대출시장의 효율성을 개선시킬 수 있을 것으로 기대된다.
\end{abstract}

핵심 단어 : $\mathrm{P} 2 \mathrm{P}$ 대출, 채무불이행 위험, 군집행동, 가격 게시형 시스템, 경매형 시스템

JEL 분류기호: G21, G23

* 연락담당 저자. 주소 서울시 광진구 능동로 120 건국대학교 경영대학, 05029; E-mail: jhseon@konkuk.ac.kr; Tel: 02-450-4099. 


\section{1. 서론}

$\mathrm{P} 2 \mathrm{P}$ 대출은 온라인상에서 다수의 개인 또는 기관투자자가 개인 또는 사업자에게 자금을 대출하는 방식이다. ${ }^{1)} \mathrm{P} 2 \mathrm{P}$ 대출은 온라인 네트워크의 발전과 더불어 등장한 핀테크의 핵심 기능 중의 하나로 전 세계적으로 급속한 성장세를 나타내고 있다. ${ }^{2)}$ 이러한 급격한 성장세는 $\mathrm{P} 2 \mathrm{P}$ 대출이 기존 금융기관의 자금공급에 대한 대안이 되는 대안금융으로서 특성에 기인 하는 바가 크다. 즉, $\mathrm{P} 2 \mathrm{P}$ 대출 플랫폼은 투자자와 차입자 간의 거래를 직접 중개함에 따라 신용도가 낮아 은행의 자금을 공급받기 어려운 차입자에 대한 자금공급의 공백을 메울 수 있다(Bruton et al., 2014). 또한 P2P 대출 플랫폼은 차입자에게 신속한 대출을 제공하고, 투자자에게는 비교적 높은 수익률을 갖는 새로운 투자기회를 제공하며, 기존 금융기관 대비 저비용의 금융중개 기능을 제공할 수 있다(Iyer et al., 2015; Jagtiani and Lemieux, 2017; WEF, 2015; Wen et al., 2017).

하지만 P2P 대출은 신용위험 평가에서 기존 금융기관과 비교하여 상대적으로 취약하다. 기존 금융기관은 차입자와 투자자 간의 정보비대칭을 경감시키고 차입자의 신용위험을 통제 하기 위해 관련 데이터와 위험 평가 시스템을 이용하여 차입자의 신용위험에 대한 전문적인 평가를 하고 있다. 반면 $\mathrm{P} 2 \mathrm{P}$ 대출에서는 투자자가 개별적으로 차입자의 신용위험을 평가를 하여야 한다. 이 업무에 충분한 경험과 전문성을 갖추지 못한 투자자가 개별적으로 차입자의 신용위험을 평가하는 쉽지 않다. 이에 따라 일부 플랫폼에서는 투자자에게 차입자에 대한 자체 신용평가 정보를 비롯한 투자정보를 제공하고 있으며, 자체 신용평가의 신뢰를 향상을 위해 신용평가 기관과 제휴하여 자체 신용평가 모델을 발전시키려고 노력하고 있다. 또한 일부 플랫폼은 대출의 투명성을 높이기 위하여 모든 대출상품의 상환 진행, 연체, 부도, 상환완료 등의 대출상황에 대한 상세한 정보를 공개하고 있다(Serrano-Cinca et al., 2015).

금융시장에서 투자자들이 불완전한 정보를 기반으로 의사결정을 내릴 때 군집행동(herding)이 발생하는 경향이 있다(Bikhchandani and Shama, 2000). 군집행동은 자신이 보유한 사적 정보에 의존하지 않고 다른 투자자들을 추종함에 따라 투자자들이 동일한 의사결정을 하는

1) $\mathrm{P} 2 \mathrm{P}$ 대출 플랫폼은 대출 및 투자 결정방식에 따라 경매형(auctions)과 가격 게시형(posted-prices) 시스템으로 구분된다(Wei and Lin, 2016). 경매형은 투자자가 대출금액과 대출금리를 제시하면 경매 프로세스를 통해 자금의 수요와 공급을 일치시키는 대출금액과 대출금리를 결정하는 방식이다. 가격 게시형은 플랫폼이 대출심사를 직접 수행한 후 미리 지정한 가격으로 하나의 차입자에 대하여 다수의 투자자를 모집하는 방식이다. 미국의 랜딩클럽과 한국의 에잇퍼센트는 가격 게시형 방식을, 한국의 팝펀딩은 경매형 방식을 취하고 있다. 미국의 프로스퍼는 경매형 방식을 취하다 가격 게시형 방식으로 전환했다.

2) Allied Market Research에 의하면, 전 세계 P2P 대출시장 규모는 2019년에 약 \$674.3억이고, 2020년 이후 연평균 $29.7 \%$ 의 성장률로 성장하여 2027년에 시장규모가 $\$ 5,589$ 억에 달할 것으로 전망된다. 국내 P2P 대출 현황에 대한 금융위원회 보도자료(2020.1.23)에 의하면, 2019년 12월 말 현재 누적 대출금액은 8 조 6,000 억 원, 대출잔액은 2 조 3,800 억 원, 차입자 수는 약 2 만 명, 개인 신용대출 비중이 $73 \%$, 전체의 대출잔액 중 부동산관련(담보 $\mathrm{PF}$ ) 대출 비중은 $66 \%$ 이다. 
Herd Behavior of Investors and Default Risks of P2P Online Lending

행위로 정의된다(Banerjee, 1992). P2P 대출 플랫폼에서는 다음 특성들로 인하여 투자자의 군집행동이 발생할 개연성이 높다.

첫째, $\mathrm{P} 2 \mathrm{P}$ 대출 시장에서 각 대출은 모집기간 중 누적 투자금액이 대출금액에 도달해야 성사된다. 많은 투자자가 투자에 참여하면, 참여한 투자자에게 원하는 투자상품에의 성공적인 투자 완료라는 혜택을 주는데, 이는 군집행동을 촉진하는 요인으로 작용할 수 있다. 즉, 모집기간에 투자자 참여가 높아져서 대출금액에 도달할 확률이 높아지면, 비록 합리적 의사 결정을 하는 투자자라고 할지라도 자신의 판단이 아닌 다른 투자자들의 결정을 추종하여 투자할 수 있다.

둘째, 투자에 참여하는 투자자 수를 관찰할 수 있는 $\mathrm{P} 2 \mathrm{P}$ 대출 플랫폼에서는 투자자의 관찰학습(observational learning)이 가능하고, 이는 투자자의 군집행동을 가져올 수 있다. 즉, 투자자들이 다른 선행 투자자들의 결정을 의도적으로 추종하여 투자 결정을 한다면, 이는 군집행동으로 볼 수 있다.

셋째, 개인투자자가 투자자의 상당 부분을 차지하는 P2P 대출시장에서 개인투자자들이 신용위험 평가에 근거한 합리적 투자 결정을 하지 않을 수 있다. 개인투자 전문가라면 그의 결정은 다른 투자자들의 영향을 거의 받지 않을 것이나, 비전문가라면 선행 투자자의 결정이 자신의 투자 결정에 영향을 미칠 수 있다. 이로 인하여 개인투자자가 분위기 또는 유행에 따라 다른 투자자들의 투자 결정을 추종하는 비합리적 투자 결정을 할 수 있다.

투자자의 군집행동은 투자자들이 다른 투자자의 행동을 의도적으로 추종하는 것을 말한다 (Bikhchandani and Shama, 2000). 따라서 투자자가 다른 투자자의 행동을 추종하려는 의도성을 갖지 못하면 군집행동이라 할 수 없으며, 이 경우 가성적 군집행동(spurious herding) 이라고 부른다. 가성적 군집행동은 시장 효율성의 저해를 가져오지 않지만, (의도적) 군집 행동은 시장효율성을 저해하는 결과를 가져온다(Bikhchandani and Shama, 2000). 이에 차입자의 신용위험에 대한 적절한 평가가 이루어진 투자자의 가성적 군집행동은 $\mathrm{P} 2 \mathrm{P}$ 대출의 채무불이행 위험에 영향을 미치지 않을 것으로 기대된다. 반면에 차입자의 신용위험에 대한 적절한 평가를 저해하는 (의도적) 군집행동은 $\mathrm{P} 2 \mathrm{P}$ 대출의 채무불이행 위험을 증가키는 요인으로 작용할 수 있다.

앞서 설명한 바와 같이 P2P 대출 플랫폼에서는 신용위험 평가의 중요성이 높고 군집행동이 나타날 개연성이 높다. 이러한 배경 하에서 본 연구는 한국의 대표 $\mathrm{P} 2 \mathrm{P}$ 플랫폼인 에잇퍼 센트의 대출 자료를 이용하여, $\mathrm{P} 2 \mathrm{P}$ 대출 시장에서 투자자의 군집행동이 대출의 채무불이행 위험에 미치는 영향을 분석하고자 한다. 그리고 이러한 분석을 통해 간접적으로 투자자의 군집행동의 발생 여부를 검증하고, 만약 투자자의 군집행동이 차입자의 신용위험에 대한 적절한 평가를 저해하는 요인으로 작용한다면 이에 대한 개선책을 제시하고자 한다. 이러한 연구는 투자자와 차입자 간의 정보비대칭 완화와 이를 통한 자금배분의 효율성 향상에 대해 시사점을 제공함으로써 학술적, 실무적 및 정책적으로 중요한 함의를 제공할 것으로 기대 된다. 
한국증권학회지 제50권 3호 (2021)

본 연구는 기존 연구들과 다음과 같은 차별성을 갖는다. 첫째, 저자가 아는 한 $\mathrm{P} 2 \mathrm{P}$ 대출 시장에서 투자자의 군집행동과 대출의 채무불이행의 연계성을 분석하는 최초의 실증연구이다. 그동안 국내외 기존 실증연구들이 차입자 관련 투자정보의 $\mathrm{P} 2 \mathrm{P}$ 대출의 상환 결과에 대한 연구, 그리고 $\mathrm{P} 2 \mathrm{P}$ 대출에서 투자자의 군집행동의 존재 유무에 대한 연구로 분리되어 이루어져 왔다. 이에 본 연구에서는 이 두 가지 유형의 선행연구의 통합을 시도한다는 점에서 차별성을 갖는다. 둘째, 경매형 플랫폼을 대상으로 한 선행연구들과 달리 본 연구는 가격 게시형 플랫폼을 대상으로 $\mathrm{P} 2 \mathrm{P}$ 대출 투자자의 군집행동을 분석한다. 경매형과 가격 게시형 플랫폼의 특성 차이가 존재하며, 이러한 특성 차이는 대출자와 차입자의 군집행동에 영향을 미칠 수 있다. 경매형은 차입자의 대출 수요와 투자자들이 제시한 투자금액의 합계인 대출 공급을 일치 시키는 경매 과정을 통해 대출금리(가격)와 대출금액(수량)을 동시에 결정하는 방식이다. 반면에 가격 게시형은 플랫폼이 직접 수행한 대출심사를 바탕으로 결정한 하나의 대출금리 (가격)로 다수의 투자자들을 대상으로 대출금액을 모집하는 방식이다. 두 방식은 개별 투자자의 투자 시점에 가격의 관찰 여부에 대한 차이가 존재한다. 가격 게시형에서는 투자자가 투자 시점에 가격의 관찰이 가능하다. 반면에 경매 과정을 통해 가격이 결정되는 경매형에서는 개별 투자자가 투자 시점에 가격을 알 수 없다. 다른 모든 조건이 동일하다면, 다른 투자자의 투자를 의도적으로 추종하는 군집행동이 경매형보다 개별 투자자들이 가격을 알고 투자하는 가격 게시형에서 더 발생할 개연성이 높다. 이에 따라 본 연구는 그동안 제시되지 못했던 가격 게시형 $\mathrm{P} 2 \mathrm{P}$ 플랫폼에서 투자자의 군집행동 발생 여부와 그 효과에 대한 실증분석 결과를 제시할 수 있을 것으로 기대된다.

본 연구에서는 개별 투자자의 식별 자료가 존재하지 않는 데이터 상의 제약으로 인해 군집행동의 존재 유무를 직접적으로 검증할 수 없는 한계를 극복하기 위하여 다음과 같은 방법론을 사용한다. 투자자의 군집행동이 채무불이행 위험에 미치는 영향은 세 가지 단계를 통해 분석된다. 첫 번째 단계에서는 투자자 수를 $\mathrm{P} 2 \mathrm{P}$ 대출 플랫폼이 제공하는 투자정보와 자금 모집 당시에 공표되는 거시경제변수(이하 공적 정보) 반영 부분과 공적 정보 제외 기타 요인(이하 기타 요인) 반영 부분으로 분해한다. ${ }^{3)}$ 즉, 투자자 수를 공적 정보에 대해 회귀분석하여 얻은 회귀식의 추정 값을 '공적 정보 반영 투자자 수로, 그리고 잔차항을 '기타 요인 투자자 수로 파악한다. 이어 두 번째 단계에서는 투자자 수와 요인 분해된 투자자 수(공적 정보 반영 투자자 수, 기타 요인 투자자 수)가 대출상환 순위변수(대출상환 성공 $=0$, 연체 $=1$, 부도=2)에 미치는 영향을 순위 프로빗 모형을 통해 추정한다. 마지막으로 이러한 분석의 결과를 통해 간접적으로 군집행동의 발생 여부에 대한 추론을 도출한다. 각 대출의 투자자 수 중 공적 정보의 영향을 받는 부분은 투자자의 행위가 군집행동이 아니라 다른 투자자를 추종하려는 의도성이 없이 공적 정보를 기반으로 하는 합리적인 결정으로 볼 수 있다. 반면 각 대출의 투자자 수 중 공적 정보의 영향을 받지 않는 부분은 다른 투자자를

3) 기타 요인에는 투자정보 및 거시경제변수 이외의 공적 정보들도 포함될 수 있다. 
Herd Behavior of Investors and Default Risks of P2P Online Lending

추종하려는 의도성이 있는 군집행동을 포함하는 부분으로 볼 수 있다. 이에 공적 정보 반영 투자자 수가 대출의 채무불이행 위험을 증가시키지 않지만, 기타 요인 투자자 수가 채무 불이행 위험을 증가시키면 투자자의 군집행동이 나타나는 것으로 판단한다. ${ }^{4}$

본 연구의 분석 결과는 다음과 같이 요약된다. 첫째, 각 대출의 투자자 수는 대출금액, 대출기간, 신용도, 사업자금 대출목적의 투자정보와 실업률, 소비자물가지수, 어음 부도율, 국고채 수익률, 종합 주가지수의 거시경제지표를 반영한다. 둘째, 각 대출의 투자자 수와 기타 요인 투자자 수의 증가는 대출의 채무불이행 위험을 증가시키지만, 공적 정보 반영 투자자 수는 채무불이행 위험을 감소시킨다. 이러한 결과는 가격 게시형 $\mathrm{P} 2 \mathrm{P}$ 대출 플랫 폼에서 공적 정보를 제외한 기타 요인으로 인해 투자자의 군집행동이 발생할 수 있으며, 이러한 군집행동은 플랫폼을 통해 제공되는 공적 정보 양의 증가 및 질의 개선을 통해 축소될 수 있음을 시사한다.

이하에서 본 연구의 구성은 다음과 같다. 제 2장에서는 선행연구를 소개한다. 이어 제 3 장에서 실증분석에 사용되는 데이터와 기술 통계량을 설명한다. 그리고 제 4 장에서는 실증 분석의 방법론과 결과를 설명한다. 마지막으로 제 5장에서 결론 및 시사점을 제시하고 본 연구를 마무리한다.

\section{2. 선행연구}

$\mathrm{P} 2 \mathrm{P}$ 대출의 상환 성공이나 채무불이행의 영향 요인을 분석한 기존 연구로 가격 게시형 플랫폼인 미국의 랜딩클럽(Lending Club)과 경매형 플랫폼인 미국의 프로스퍼(Prosper), 한국의 팝편딩(Popfunding) 등을 대상으로 한 실증연구들이 있다. 한편 미국의 프로스퍼, 한국의 팝펀딩 등 경매형 플랫폼을 대상으로 $\mathrm{P} 2 \mathrm{P}$ 대출 투자자의 군집행동을 분석한 실증 연구들이 존재한다. 이하에서는 본 연구와 관련된 이러한 선행연구를 $\mathrm{P} 2 \mathrm{P}$ 대출의 채무불 이행 연구와 P2P 대출의 군집행동 연구로 나누어 살펴보고자 한다.

\subsection{P2P 대출의 채무불이행 연구}

투자자가 차입자의 신용을 평가하는데 사용될 수 있도록 플랫폼에서 제공하는 정보의 유형과 이러한 정보들이 차입자의 채무불이행을 얼마나 효과적으로 추론하는지에 대하여 미국의 프로스퍼와 랜딩클럽, 한국의 팝펀딩 $\mathrm{P} 2 \mathrm{P}$ 대출 등을 대상으로 한 실증연구들이 있다.

Carmichael et al.(2014)은 랜딩클럽 데이터(2007년 2014년)에서 차입자의 대출신청금액 증가, Fair, Isaac and Company(이하 FICO) 점수 감소, 신용등급 하락이 채무불이행 증가를, 차환대출, 카드상환, 주택개선의 대출목적, 연 수입 증가, Debt-to-Income(이하 DTI) 감소, 대출문의 감소는 채무불이행 감소를 각각 가져온다는 결과를 발견한다. Mach et al.(2014)은

4) 이에 대한 구체적인 내용은 제 4.1절 방법론을 참조하길 바란다. 
한국증권학회지 제 50 권 3호 (2021)

랜딩클럽 데이터(2007년 2012년)를 이용한 소기업 대출의 채무불이행 영향 분석에서 대출 금액 증가, $\mathrm{FICO}$ 점수 감소, 연 소득 감소, 대출기간 증가가 채무불이행이 증가하는 결과를 제시한다. Emekter et al.(2015)은 랜딩클럽 데이터(2007년 2012년)로 차입자의 신용등급 하락과 FICO 점수 감소 등 신용위험이 높아지면 채무불이행 위험이 증가하는 것을 발견 한다. Serrano-Cinca et al.(2015)은 랜딩클럽 데이터(2008년 2014년)에서 차입자의 대출 금리 감소, DTI 감소, 대출문의 감소가 채무불이행 위험 증가를 가져오는 것을 보고한다. Nowak et al.(2018)의 랜딩클럽 데이터(2007년 2014년) 연구는 소기업 대출에서 차입자의 연 수입 감소, 대출금리 감소, FICO 점수 감소가 채무불이행의 증가를 가져온다는 결과를 제시한다. Polena and Regner(2018)는 랜딩클럽 데이터(2009 2012)를 이용한 차입자 부도 결정요인 분석에서 대출금액 증가, 연 수입 감소, DTI 증가, 대출문의 및 연체 건수 증가가 부도위험의 증가 요인이라는 것을 보고한다. Freedman and $\operatorname{Jin}(2008)$ 은 프로스퍼 (2006년 2008년) 데이터를 이용한 채무불이행 영향요인 분석에서 신용등급 감소, 대출 금액 증가, DTI 증가, 연체정보 감소가 부도와 연체 위험의 증가요인이라는 결과를 제시 한다.

Shin and Chae(2012)은 팝펀딩 데이터(2008년 2011년)에서 대출금액이 증가하거나 월 소득이 감소하거나, 신용조회 건수가 증가하거나 특수기록(면책, 회생 등 기록 유무 등)이 감소하면 채무불이행이 증가하는 결과를 제시한다. Kim and Park(2013)은 팝펀딩 데이터 (2008년 2010년)를 이용한 분석에서 대출금액과 대출금리가 감소하면 상환성공이 증가하고, 차입자 직업이 비상근직이고 부채상환비용이 증가하면 상환성공이 감소함을 발견한다. Kim et al.(2013)은 팝펀딩 데이터(2008년 2010년)로 신용위험이 감소하거나 신용파산 경험이 있는 경우와 부채상환비용, 주거비용, 생활비용, 의료비용의 대출목적은 상환성공을 증가시키는 경향이 있음을 확인하고 있다.

\subsection{P2P 대출의 군집행동 연구}

$\mathrm{P} 2 \mathrm{P}$ 대출에서 군집행동에 대한 선행연구는 주로 미국의 프로스퍼, 한국의 팝펀딩, 중국 렌렌다이(Renrendai) 등 경매형 $\mathrm{P} 2 \mathrm{P}$ 대출 플랫폼을 대상으로 한다. 경매형 $\mathrm{P} 2 \mathrm{P}$ 대출 플랫폼을 통하여 이루어지는 $\mathrm{P} 2 \mathrm{P}$ 대출은 다수의 투자자가 입찰에 참여하면 경매를 통하여 결정된 대출 금리와 금액으로 차입자에게 자금을 공급하는 대출 형태이다. 다수의 투자자 들이 참여하다 보니 입찰의 참여 여부 고려 시 선행 입찰 참여자들의 결정을 의도적으로 추종하는 군집행동이 발생할 수 있다. 이에 선행연구들은 경매형 $\mathrm{P} 2 \mathrm{P}$ 대출 플랫폼에서 입찰 참여자의 군집행동의 존재 여부와 군집행동의 합리성 또는 비합리성 여부에 중점을 두고 있다.

Herzenstein et al.(2011)은 프로스퍼 데이터(2006년 6월)에서 경매형 플랫폼에서 입찰이 많을수록 투자자의 입찰 참여 확률이 높아지는 투자자의 전략적 군집행동의 증거를 발견 하고, 이러한 투자자의 전략적 군집행동이 투자자에게 개인적 및 집단적으로 혜택을 준다는 
Herd Behavior of Investors and Default Risks of P2P Online Lending

결과를 제시한다. Lee and Lee(2012)의 한국 팝펀딩 데이터(2009년 2010년) 연구는 $\mathrm{P} 2 \mathrm{P}$ 대출 투자자들의 강한 군집행동을 발생하지만 입찰이 진행될수록 한계적으로 발생하는 군집행동은 감소함을 발견한다. Zhang and Liu(2012)은 프로스퍼 데이터(2006년 2월 2008년 9월)에서 투자자의 합리적 군집행동의 증거를 발견하고, 이러한 군집행동은 투자자가 공개적으로 관찰 가능한 차입자의 특성과 함께 다른 투자자들의 대출 결정을 이용하여 차입자의 신용도를 추론하는 관찰 학습을 진행에 따라 발생하는 것으로 해석한다. Zhang and Chen(2017)은 렌렌다이 데이터(2010년 2015년)를 이용하여 누적 입찰 참여와 현재 입찰 참여 간의 동적인 관계를 분석하고 $\mathrm{P} 2 \mathrm{P}$ 대출시장에서 합리적 군집행동과 비합리적 군집행동이 존재함을 발견한다.

\section{3. 데이터 및 기술 통계량}

\section{1 데이터}

본 연구는 한국의 대표 P2P 대출 플랫폼인 에잇퍼센트를 연구 대상으로 한다. 에잇퍼 센트는 2014년 설립되어 2019년 말 기준으로 누적 대출금액이 약 2,775억 원을 기록하고 있으며, 한국에서 개인과 소기업에 대한 신용대출을 가장 많이 취급하고 있다. P2P 대출은 대출의 차입자 유형, 금리 결정 방식, 심사 방식, 중개 방식, 담보유무에 따른 대출 종류 등에 따라 특성이 구분될 수 있다. 에잇퍼센트의 대출의 경우, 차입자 유형에서 개인 및 소기업 사업자에 대한 신용대출로, 금리 결정 방식에서 고정이자율 방식으로, 심사 방식에서 플랫폼이 대출심사를 직접 수행하는 방식으로, 중개방식에서 한 차입자에 대하여 다수의 투자자를 모집하는 일대다 대출 중개방식으로 각각 분류될 수 있다. 한편 에잇퍼센트는 대표적인 $\mathrm{P} 2 \mathrm{P}$ 온라인 대출 플랫폼인 미국의 랜딩클럽과 유사한 가격 게시형 플랫폼 운영 방식을 취하고 있으며, 차입자의 개인신용 및 상환능력을 고려한 자체 신용평가 시스템을 갖추고 있다. ${ }^{5)}$

본 연구에 사용되는 데이터는 에잇퍼센트 플랫폼을 통해 2015년 2월부터 2017년 12월

5) 에잇퍼센트는 대출 신청서와 함께 대출 신청자의 소득, 연체 이력, 개인 신용평가 점수 등 개인 신용평가 회사로부터 제공받은 금융 데이터를 대출자 신용분석을 위한 기본 데이터로 활용한다. 그러나 금융 데이터가 충분히 제공되지 않는 중간 신용등급의 경우에는 사회관계망 서비스를 통해 확보하는 비정형 데이터, 심리분석 데이터 등 다양한 비금융 데이터를 수집하여 분석함으로써 부족한 금융 데이터를 보완한다. 에잇퍼센트의 경우, 자체 개발한 인공지능 기반 신용평가시스템이 수집한 데이터를 기반으로 대출자의 신용도를 평가하고 있다. 빅 데이터와 머신러닝을 활용하는 이 시스템에 대한 상세한 내용은 외부에 공개되지 않고 있다. P2P 플랫폼과 은행 대출의 개인 신용평가는 신용분석의 주체와 대상에 있어서 차이가 있다. 기존 은행대출에서의 신용평가는 대출 신청자의 신용정보, 금융거래 실적, 부채, 소득 비율 및 연체 정보 등 재무상황이 주요 분석 대상이 되며, 숙련된 금융전문가에 의해 이루어진다. 한편, $\mathrm{P} 2 \mathrm{P}$ 플랫폼은 은행 대출에서 평가가 상대적으로 적게 이루어지는 중간 등급 신용자에 대한 신용분석이 많이 이루어지고 있다. 
한국증권학회지 제 50 권 3호 (2021)

까지 이루어진 3,720 건의 대출 상품에 대한 횡단면 자료 ${ }^{6)}$ 와 한국은행 사이트에서 수집된 거시경제지표 시계열 자료로 구성된다. <표 1>은 본 연구에 사용되는 투자상품 특성, 투자정보, 거시경제지표 변수에 대한 정의를 제시한다.

〈표 1〉변수의 정의

이 표는 분석에 사용되는 변수에 대한 정의를 제시하고 있다.

\begin{tabular}{|c|c|}
\hline 변수 & 정의 \\
\hline \multicolumn{2}{|l|}{ 투자상품 특성: } \\
\hline 투자자 수 & 각 투자상품에 참여한 투자자 수(명) \\
\hline 채무불이행 정도 & $\begin{array}{l}\text { 대출금액과 이자가 전액 상환되거나 만기 이전에 조기 상환된 경우 }=0 \text {, 대출 } \\
\text { 금액과 이자의 상환이 } 89 \text { 일 이하 상환지연으로 연체로 처리된 경우 } 1 \text {, 상환이 } \\
90 \text { 일 이상 초과하여 부도로 처리된 경우 } 2 \text { 의 값을 갖는 순위 변수 }\end{array}$ \\
\hline \multicolumn{2}{|r|}{ - } \\
\hline 대출금액 & 차입자가 신청하고 플랫폼에서 확정된 총 대출금액 \\
\hline 대출금리 & 투자상품에 대한 연간 투자수익률(\%) \\
\hline 대출기간 & 투자상품의 대출만기 정보(년) \\
\hline 신용도 & $\begin{array}{l}\text { 플랫폼 자체 평가 신용신용등급으로 } 1 \text { 11 등급으로 분류(1등급을 최저 } \\
\text { 신용도(신용위험이 가장 높은 저 신용등급), } 11 \text { 등급을 최고 신용도(신용 } \\
\text { 위험이 가장 낮은 고 신용등급)로 구분) }\end{array}$ \\
\hline 대출목적 & $\begin{array}{l}\text { '사업자금’, ‘차환대출' 및 '개인자금’으로 분류되는 해당 대출목적이 } 1 \text { 의 값을 } \\
\text { 갖는 더미변수 }\end{array}$ \\
\hline \multicolumn{2}{|l|}{ 거시경제지표: } \\
\hline 실업률 & 통계청의 경제활동인구조사 월별 자료(\%) \\
\hline 소비자물가지수 & 2015년 기준의 월별 소비자물가지수 \\
\hline 어음 부도율 & 전자결제분이 제외된 어음부도율(\%) \\
\hline 국고채 수익률 & 3년 만기 국고채 수익률(\%) \\
\hline 종합주가지수 & 월평균 종합주가지수 \\
\hline
\end{tabular}

투자상품 특성 변수는 각 투자상품에 투자한 투자자 수와 2018년 10월 기준으로 파악한 대출의 채무불이행 정도(상환 성공 $=0$, 연체 $=1$, 부도 $=2$ )로 구성된다. 투자정보는 $\mathrm{P} 2 \mathrm{P}$ 대출 플랫폼에서 투자자에게 제공하는 대출 조건과 차입자의 신용도 정보로 구성된다. 대출금액은 차입자가 신청하고 플랫폼에서 확정한 총 대출금액이며, 대출금리는 투자상품에서 제시하는 연간 투자수익률(\%)이다. 대출기간은 투자상품의 대출 만기(년)이다. 신용도는 $\mathrm{KCB}$ 신용

6) 2018년 10월 기준으로 에잇퍼센트의 사이트(https://8percent.kr/investments/history)에서 횡단면 대출 상품 데이터를 수집하였다. 표본 기간 중 발생한 총 4,379건의 대출 중에서 2015년 에잇퍼센트의 초기 투자 상품으로 투자 모집 기간이 60일 이상이거나 투자자 수가 1인이거나 2018년 10월 기준으로 상환이 진행 중인 659건의 대출은 분석 결과의 편의가 예상되므로 분석에서 제외하였다. 에잇퍼센트의 홈페이지 개편으로 이 회사의 투자 상품 조회 웹 사이트 주소가 "https://8percent. $\mathrm{kr} / \mathrm{deals} /$ ”로 변경되었고, 제공되는 대출 상품 정보의 구성도 일부 변경되어 대출모집 기간, 대출 종료일 등의 정보가 더 이상 제공되지 않게 되었다. 
Herd Behavior of Investors and Default Risks of P2P Online Lending

평가사의 신용등급과 다양한 비금융정보를 활용하여 에잇퍼센트 자체 신용평가시스템이 제시하는 차입자의 신용등급 체계이다. 차입자 신용도는 $\mathrm{A}, \mathrm{B}, \mathrm{C}, \mathrm{D}$ 그룹으로 분류되고, $\mathrm{A} \sim \mathrm{D}$ 의 그룹은 다시 11 1 등급으로 세분화된다. 1등급을 최저 신용도(신용위험이 가장 높은 저 신용등급)으로 11 등급을 최고 신용도(신용위험이 가장 낮은 고 신용등급)으로 분류 한다. $\mathrm{P} 2 \mathrm{P}$ 대출 플랫폼이 제공하는 차입자의 대출목적 정보는 사업자금, 차환대출 및 개인 자금으로 분류하며, 주거자금, 구매자금 등 낮은 구성 비율의 대출목적은 분석에서 제외한다. 거시경제지표 자료는 투자모집이 진행된 해당 월의 자료를 사용한다. 플랫폼에서 대출의 투자모집 발생시기에 대한 정보는 제공되나, 부도 또는 연체 발생시기에 대한 정보가 제공되지 않기 때문에 각 대출의 투자모집 시기의 거시경제지표를 분석에 적용한다. ${ }^{7)}$ 실업률(\%)은 통계청의 경제활동인구조사 월별 자료이고, 소비자물가지수는 2015년 기준 월별 소비자물가지수이다. 어음부도율 $(\%)$ 은 전자결제분이 제외된 부도율이며, 국고채 수익률(\%)은 3 년 만기 수익률 이고, 종합주가지수는 월평균 지수이다.

\section{2 기술 통계량}

<표 2>는 본 연구의 주요 분석변수에 대한 기술 통계량을 제시한다. P2P 대출 투자상품 건당 투자자 수는 평균 194 명이다. 분석대상 투자상품의 건당 평균 대출금액은 1,535 만 원이며, 평균 대출금리는 $9.6 \%$, 평균 대출기간은 1.5 년이다. 이와 같은 건당 평균 투자자 수 및 대출금액은 다수의 투자자가 $\mathrm{P} 2 \mathrm{P}$ 대출에 참여하여 소액 분산투자를 하고 있음을 함의한다. 차입자의 대출목적 더미변수의 평균 값은 차환대출(0.412), 개인자금(0.362), 사업자금(0.138)의 순으로 크게 나타나며, 이는 차입자의 대출목적이 차환대출, 개인자금, 사업자금 순으로 많음을 시사한다.

<표 3>은 에잇퍼센트의 자체 신용평가시스템으로 분류된 신용그룹별로 계산된 주요 분석 변수의 평균 값을 보고한다. 신용그룹A(신용그룹 $\mathrm{D}$ )는 신용위험이 가장 낮은(높은) 그룹 이다. 신용이 양호한 그룹일수록 평균 투자자 수가 증가한다. 신용이 양호한 신용그룹에서 건당 평균 대출금액이 증가하고, 평균 대출금리는 감소하며 평균 대출기간이 증가하는 경향을 보인다. 신용이 양호한 그룹일수록 대출 목적이 사업자금이나 개인자금인 경우가 많고, 차환대출인 경우는 적게 나타난다. 에잇퍼센트의 신용평가시스템 내용이 공개되지 않아 기존 금융권의 신용등급과 정확한 비교가 어렵지만, 기존 금융에서 자금조달이 어려울 것으로 추정되는 C, D신용그룹의 차입자가 P2P 대출 플랫폼에서 $10 \%$ 대의 중금리로 대출을 받고 있는 것으로 나타난다. 전체 표본에서 대출의 상환 성공, 연체, 부도가 차지하는 비율은 각각 $87.7 \%, 4.4 \%, 7.9 \%$ 이다. 신용이 양호한 그룹일수록, 대출의 상환 성공 비율은 높고, 연체 및 부도 비율은 낮게 나타난다.

7) 에잇퍼센트 플랫폼에서 조기상환 완료 시점과 연체 또는 부도 발생 시점에 대한 데이터가 제공 되지 않고 있다. 이로 인해 각 대출의 상환 완료, 부도 및 연체의 발생 시점과 일치하는 거시경 제지표를 적용하지 못하는 자료 상의 제약이 있다. 


\section{〈표 2〉기술 통계량}

이 표는 주요 변수의 기술 통계량을 제시하고 있다. 투자자 수는 대출상품에 참여한 투자자 수(천명)이다. 대출금액은 차입자가 신청하고 플랫폼에서 확정한 총 대출금액(천 만원)이여, 대출금리는 대출상품에 대한 연간 투자수익률(\%)이다. 대출기간은 대출상품의 대출만기(년)이고, 신용도는 플랫폼에 제시하는 차입자의 신용등급 정보이다. 사업자금, 차환대출 및 개인자금 더미는 대출목적이 해당 목적인 경우 1 의 값을 갖는 더미변수이다. 거시경제변수는 투자모집이 개시된 해당 월의 경제지표로 측정되며, 실업률 $(\%)$ 은 통계청의 경제활동인구조사 월별 자료, 소비자물가지수(백 포인트)는 2015년 기준의 월별 소비자물가지수이다. 어음 부도율은 전자결제분이 제외된 어음 부도율(\%), 국고채 수익률은 3 년 만기 국고채 수익률(\%), 종합주가지수는 월평균 종합물가지수(천 포인트)이다.

\begin{tabular}{lccccccc}
\hline \multicolumn{1}{c}{ 변수명 } & 평균 & 중간값 & 최대값 & 최소값 & 표준편차 & 왜도 & 첨도 \\
\hline 투자자 수 & 0.194 & 0.120 & 2.283 & 0.010 & 0.214 & 2.772 & 14.11 \\
대출금액 & 1.535 & 1.000 & 40.00 & 0.020 & 3.039 & 7.563 & 71.18 \\
대출금리 & 9.608 & 9.150 & 19.37 & 4.390 & 2.462 & 0.518 & 2.708 \\
대출기간 & 1.497 & 1.000 & 3.000 & 0.083 & 0.639 & 0.888 & 3.025 \\
신용도 & 5.594 & 6.000 & 11.00 & 1.000 & 2.386 & 0.036 & 2.176 \\
사업자금 더미 & 0.138 & 0.000 & 1.000 & 0.000 & 0.345 & 2.104 & 5.425 \\
차환대출 더미 & 0.412 & 0.000 & 1.000 & 0.000 & 0.492 & 0.359 & 1.129 \\
개인자금 더미 & 0.362 & 0.000 & 1.000 & 0.000 & 0.481 & 0.575 & 1.331 \\
실업률 & 3.628 & 3.600 & 4.900 & 3.000 & 0.461 & 1.293 & 4.519 \\
소비자물가지수 & 1.019 & 1.026 & 1.035 & 0.998 & 0.012 & -0.178 & 1.452 \\
어음 부도율 & 0.136 & 0.100 & 0.370 & 0.050 & 0.070 & 1.597 & 5.354 \\
국고채 수익률 & 1.648 & 1.680 & 2.150 & 1.220 & 0.207 & 0.118 & 3.484 \\
종합주가지수 & 2.158 & 2.062 & 2.534 & 1.895 & 0.199 & 0.433 & 1.662 \\
\hline
\end{tabular}

〈표 3〉 주요 변수의 신용그룹별 기술 통계량

이 표는 신용그룹별 주요 변수의 평균값을 보고하고 있다. 투자자 수는 대출상품에 참여한 투자자 수(천명)이다. 대출금액은 차입자가 신청하고 플랫폼에서 확정한 총 대출금액(천 만원)이여, 대출금리는 대출상품에 대한 연간 투자수익률(\%)이다. 대출기간은 대출상품의 대출만기(년)이고, 신용도는 플랫폼에 제시하는 차입자의 신용등급 정보이다. 사업자금, 차환대출 및 개인자금 더미는 대출목적이 해당 목적인 경우 1 의 값을 갖는 더미변수이다. 이 표에는 각 신용그룹의 상환 성공, 연체 및 부도가 해당 그룹의 대출 건수에서 차지하는 비율이 보고되고 있다.

\begin{tabular}{lccccc}
\hline & 전체 표본 & $\begin{array}{c}\text { 신용그룹 } \mathrm{A} \\
(11-9 \text { 등급 })\end{array}$ & $\begin{array}{c}\text { 신용그룹 } \mathrm{B} \\
(8-6 \text { 등급 })\end{array}$ & $\begin{array}{c}\text { 신용그룹 } \mathrm{C} \\
(5-3 \text { 등급 })\end{array}$ & $\begin{array}{c}\text { 신용그룹 } \mathrm{D} \\
(2-1 \text { 등급 })\end{array}$ \\
\hline 투자자 수 & 0.272 & 0.211 & 0.164 & 0.147 \\
대출금액 & & 3.536 & 1.705 & 0.947 & 0.732 \\
대출금리 & 6.732 & 8.377 & 10.73 & 13.38 \\
대출기간 & 1.530 & 1.546 & 1.486 & 1.321 \\
신용도 & & 9.514 & 6.934 & 4.031 & 1.759 \\
사업자금 더미 & & 0.255 & 0.177 & 0.087 & 0.037 \\
차환대출 더미 & & 0.131 & 0.345 & 0.510 & 0.625 \\
개인자금 더미 & & 0.433 & 0.370 & 0.346 & 0.310 \\
대출 건수 & 3,720 & 436 & 1,518 & 1,334 & 432 \\
상환 성공 & 0.877 & 0.913 & 0.902 & 0.850 & 0.836 \\
연체 & 0.079 & 0.048 & 0.063 & 0.010 & 0.104 \\
부도 & 0.044 & 0.039 & 0.035 & 0.050 & 0.060 \\
\hline
\end{tabular}


Herd Behavior of Investors and Default Risks of P2P Online Lending

주요 변수 간의 상관관계는 <표 4>에 제시되어 있다. 투자자 수는 대출금액, 대출금리, 대출기간, 신용도, 어음부도율 및 종합주가지수와 통계적으로 유의한 상관관계를 보인다. 대출금액은 대출금리, 대출기간, 신용도와, 대출금리는 대출기간, 신용도, 어음부도율과 각 각 통계적으로 유의한 상관관계를 갖는다.

〈표 4〉 주요 변수 간의 상관관계

이 표는 주요 변수 간의 상관관계를 보고하고 있다. 투자자 수는 대출상품에 참여한 투자자 수(천 명)이다. 대출금액은 차입자가 신청하고 플랫폼에서 확정한 총 대출금액(천 만원)이여, 대출금리는 대출상품에 대한 연간 투자수익률 $(\%)$ 이다. 대출기간은 대출상품의 대출만기(년)이고, 신용도는 플랫폼에 제시하는 차입자의 신용등급 정보이다. 거시경제변수는 투자모집이 개시된 해당 월의 경제지표로 측정되며, 실업률(\%)은 통계청의 경제활동인구조사 월별 자료, 소비자물가지수(백 포인트)는 2015년 기준의 월별 소비자물가지수이다. 어음 부도율은 전자결제분이 제외된 어음 부도율 $(\%)$, 국고채 수익률은 3 년 만기 국고채 수익률 $\%$, 종합주가지수는 월평균 종합주가지수(천 포인트)이다.

\begin{tabular}{lrrrrrrr}
\hline 상관관계(P-값) & \multicolumn{1}{c}{$(1)$} & \multicolumn{1}{c}{$(2)$} & \multicolumn{1}{c}{$(3)$} & $(4)$ & (5) & (6) & (7) \\
\hline (1) 투자자 수 & 1 & & & & & & \\
(2) 대출금액 & 0.345 & 1 & & & & & \\
& $(0.00)$ & - & & & & & \\
(3) 대출금리 & -0.136 & -0.110 & 1 & & & & \\
(4) 대출기간 & $(0.00)$ & $(0.00)$ & - & & & & \\
& -0.270 & -0.047 & 0.200 & 1 & & & \\
(5) 신용도 & $(0.00)$ & $(0.00)$ & $(0.00)$ & - & & & \\
& 0.182 & 0.258 & -0.809 & 0.073 & 1 & & \\
(6) 어음부도율 & $(0.00)$ & $(0.00)$ & $(0.00)$ & $(0.00)$ & - & & \\
& -0.111 & -0.023 & -0.072 & -0.035 & -0.023 & 1 & \\
(7) 종합주가지수 & $(0.00)$ & $(0.16)$ & $(0.00)$ & $(0.03)$ & $(0.15)$ & - & \\
& 0.502 & -0.022 & 0.021 & -0.559 & -0.125 & 0.121 & 1 \\
\hline
\end{tabular}

\section{4. 실증분석}

\section{1 방법론}

본 연구는 $\mathrm{P} 2 \mathrm{P}$ 대출 시장에서 투자자의 군집행동을 실증적으로 분석하는 것을 목적으로 한다. 하지만 각 대출에서 개별 투자자를 식별할 수 있는 정보가 없어 투자자의 군집행동을 직접적으로 측정할 수 없다. 이러한 한계로 인하여 본 연구에서는 이하에서 설명하는 방식 으로 군집행동의 발생 유무와 그 효과를 검증하고자 한다.

\subsection{1 투자자 수의 요인 분해}

먼저 본 연구에서는 군집행동의 측정변수로 대출자금의 모집이 성공적으로 완료된 투자 상품에서 모집기간 중 투자에 참여한 투자자의 수를 사용한다. 각 투자상품에서 투자자 수가 P2P 대출에서 투자자 군집행동의 경향을 파악할 수 있는 변수로 볼 수 있는 근거는 
한국증권학회지 제 50 권 3호 (2021)

다음과 같다. 가격 게시형 플랫폼에서 개별 투자자가 어떤 투자상품에 투자할지 여부를 결정할 때, 이미 참여한 투자자의 수를 확인할 수 있다. 이때 다른 투자자들이 많이 참여한 투자상품은 투자를 고려 중인 투자자에게 매력적인 투자상품으로 인식될 수 있다. 이처럼 다른 투자자의 투자 참여도를 고려하여 이루어지는 투자자의 개별적인 투자 참여 결정은 각 투자상품에서 투자자 수로 합산된 결과이다.

합리적 의사결정을 하는 개별 투자자라면 어떤 투자상품에 투자할지 여부를 결정할 때, 대출금액, 대출금리, 대출기간, 차입자의 신용도 등 $\mathrm{P} 2 \mathrm{P}$ 대출 플랫폼에서 제공되는 투자 정보와 자금모집 당시 공표되는 거시경제지표와 같은 공적 정보를 고려하여 결정할 것이다. 이에 따라 자금모집이 완료된 각 투자상품에 참여한 투자자 수는 이러한 공적 정보를 반영할 가능성이 높다. 선행연구의 결과를 근거로 판단하여도 각 $\mathrm{P} 2 \mathrm{P}$ 대출의 투자자 수가 투자 정보와 거시경제지표의 영향을 받는 것으로 예상할 수 있다(〈표 5> 참조).

\section{〈표 5〉 주요 변수의 투자자 수 및 채무불이행 영향 예상부호}

이 표는 $\mathrm{P} 2 \mathrm{P}$ 대출플랫폼이 제공하는 각 투자정보 변수들이 투자자 수와 채무불이행 정도에 미치는 영향에 대한 부호를 선행연구 결과를 기반으로 예상하고 있다.

\begin{tabular}{|c|c|c|c|c|}
\hline 정보내용 & 선행연구 & 분석대상 및 영향 부호 & 투자자 수 & 채무불이행 \\
\hline 대출금액 증가 & $\begin{array}{l}\text { Shin and Chae(2012) } \\
\text { Kim and Park(2013) } \\
\text { Carmichael et al.(2014) } \\
\text { Feng et al.(2015) } \\
\text { Mach et al.(2014) }\end{array}$ & $\begin{array}{l}\text { 대출상환 성공 }(-) \\
\text { 대출상환 성공 }(-) \\
\text { 채무불이행 (+) } \\
\text { 투자자 수 (+) } \\
\text { 소기업 채무불이행 (+) }\end{array}$ & + & + \\
\hline 대출금리 증가 & $\begin{array}{l}\text { Kim and Park(2013) } \\
\text { Feng et al.(2015) } \\
\text { Nowak et al.(2018) } \\
\text { Serrano-Cinca et al.(2015) }\end{array}$ & $\begin{array}{l}\text { 대출상환 성공 (-) } \\
\text { 투자자 수 (+) } \\
\text { 소기업 채무불이행 (-) } \\
\text { 채무불이행 (-) }\end{array}$ & + & $+/-$ \\
\hline 대출기간 증가 & $\begin{array}{l}\text { Feng et al.(2015) } \\
\text { Mach et al.(2014) }\end{array}$ & $\begin{array}{l}\text { 투자자 수 }(-) \\
\text { 소기업 채무불이행 (+) }\end{array}$ & - & + \\
\hline 신용도 하락 & $\begin{array}{l}\text { Kim et al.(2013) } \\
\text { Emekter et al.(2015) } \\
\text { Feng et al.(2015) } \\
\text { Mach et al.(2014) }\end{array}$ & $\begin{array}{l}\text { 대출상환 성공 (-) } \\
\text { 채무불이행 (+) } \\
\text { 투자자 수 }(-) \\
\text { 소기업 자금모집 (-) }\end{array}$ & - & + \\
\hline 대출목적 & $\begin{array}{l}\text { Kim et al.(2013) } \\
\text { Carmichael et al.(2014) } \\
\text { Polena and Regner(2018) }\end{array}$ & $\begin{array}{l}\text { 대출상환 성공 (+) } \\
\text { 채무불이행 (-) } \\
\text { 채무불이행 (+/-) }\end{array}$ & $+/-$ & $+/-$ \\
\hline 거시경제지표 & Mach et al.(2014) & $\begin{array}{l}\text { 자금조달 및 금리 (+/-) } \\
\text { 채무불이행 }(+/-)\end{array}$ & $+/-$ & $+/-$ \\
\hline
\end{tabular}

이러한 배경 하에 각 대출의 투자자 수를 종속변수로 하고 공적 정보인 투자정보와 거시 경제지표를 설명변수로 하는 식 (1)을 회귀분석을 통해 추정한다. 식 (1)의 추정값(fitted value)은 공적 정보를 반영하는 투자자 수(이하 공적 정보 반영 투자자 수)를, 식 (1)의 
Herd Behavior of Investors and Default Risks of P2P Online Lending

잔차항(residual)은 공적 정보 이외 기타 요인을 반영하는 투자자 수(기타 요인 투자자 수)를 각각 의미한다.

$$
\begin{aligned}
& \text { 투자자 수 }{ }_{i}=\alpha_{0}+\beta_{1} \text { 대출금액 }{ }_{i}+\beta_{2} \text { 대출금리 } i_{i}+\beta_{3} \text { 대출기간 }{ }_{i}+\beta_{4} \text { 신용도 }{ }_{i}+\beta_{5} \text { 사업자금 더미 } \\
& +\beta_{6} \text { 차환대출 더미 }{ }_{i}+\beta_{7} \text { 개인자금 더미 }{ }_{i}+\beta_{8} \text { 실업률 }{ }_{i}+\beta_{9} \text { 소비자물가지수 }{ }_{i}
\end{aligned}
$$

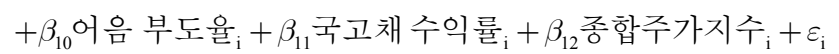

\subsection{2 요인 분해된 투자자수의 채무불이행 영향 분석}

이번 단계에서는 요인 분해된 투자자 수가 채무불이행 위험의 증가를 가져오는지를 확인 한다. 이를 위해 각 대출의 상환 성공 $(=0)$, 연체 $(=1)$, 부도 $(=2)$ 의 3 단계의 상환결과 순위 변수를 종속변수로 하고 투자자 수와 요인 분해된 투자자 수를 설명변수로 하는 모형 1 모형 3 을 추정한다.

모형 1: 상환결과 ${ }_{1}=\alpha_{0}+\beta_{1}$ 투자자 수 $+\sum \gamma_{\mathrm{ki}}$ 통제변수 ${ }_{\mathrm{k}, \mathrm{i}}+\varepsilon_{\mathrm{i}}$

모형 2: 상환결과 ${ }_{\mathrm{I}}=\alpha_{0}+\beta_{\mathrm{I}}$ 기타 요인 투자자 수 $+\sum \gamma_{\mathrm{ki}}$ 통제변수 ${ }_{\mathrm{i}}+\varepsilon_{\mathrm{i}}$

모형 3: 상환결과 ${ }_{1}=\alpha_{0}+\beta_{1}$ 기타 요인 투자자 수 $+\beta_{2}$ 공적 정보 반영 투자자 수 $+\varepsilon_{\mathrm{i}}$

여기서 오차항 $\left(\varepsilon_{\mathrm{i}}\right)$ 는 독립적인 확률변수로 정규분포를 갖는다고 가정한다.

종속변수인 상환결과는 상환 성공 $(=0)$, 연체 $(=1)$, 부도 $(=2)$ 의 3 단계의 대출결과 순위변수이다. 상환 성공은 대출금액과 대출이자가 대출기간이 만료되어 전액 상환되거나 만기 이전에 조기 상환된 경우, 연체는 30일 이상, 89일 이하 상환이 지연되어 연체로 처리된 경우, 부도는 대출금액과 대출이자의 상환이 90 일 이상 초과하여 연체되어 부도 처리된 경우가 각각 해당된다. 모형 1에는 투자자 수를, 모형 2에서는 기타 요인 투자자 수를, 모형 3에서는 기타 요인 투자자 수와 공적 정보 반영 투자자 수를 각각 설명변수로 한다. 모형 1 3의 추정을 위해 순위 프로빗 모형을 사용한다. 그 이유는 종속변수가 서열관계를 갖는 순위변수이며 오차항이 정규분포를 따르므로 순위 프로빗 모형이 적합한 분석 방법으로 판단되기 때문이다.

$\mathrm{P} 2 \mathrm{P}$ 대출에서 차입자의 성공적인 대출상환이나 연체와 부도의 채무불이행이 발생할 확률은 플랫폼에서 제공하는 투자정보(대출금액, 대출금리, 대출기간, 신용도, 대출목적)와 경제환경 (실업률, 소비자물가지수, 어음 부도율 등)의 영향을 받을 수 있다. Carmichael et al. (2014), Polena and Regner(2018) 등 에잇퍼센트와 유사한 가격 게시형 플랫폼인 랜딩클럽에 대한 선행연구에서 대출금액, 대출금리, 대출기간, 대출목적 등 투자정보가 $\mathrm{P} 2 \mathrm{P}$ 대출의 상환 성공이나 채무불이행의 주요 영향요인임을 보고한다(<표 5> 참조).

<표 6>은 상환 성공, 연체, 부도에 대한 더미 변수를 종속변수로 하고 주요 분석변수를 설명변수로 하는 로짓 회귀분석의 결과를 제시한다. 투자정보 변수에 대한 부호는 대출금액을 제외하고는 선행연구를 기반으로 예상한 <표 5>의 영향 부호와 대체로 동일하게 나타난다. 
한국증권학회지 제50권 3호 (2021)

대출금액은 상환 성공, 연체 및 부도 확률에 통계적으로 유의한 영향을 미치지 못하는 것으로 나타난다. 대출금리의 상승은 상환 성공의 확률을 낮추고, 연체의 확률을 높이는 것으로 나타난다. 대출기간의 증가는 상환 성공과 연체의 확률은 낮추지만, 부도의 확률을 높이는 것으로 나타난다. 신용도의 상승은 상환 성공의 확률을 높이고, 부도의 확률을 낮추는 것으로 나타난다. 대출 목적이 차환대출이면, 상환 성공의 확률이 높아지고 부도의 확률은 낮아 진다. 대출 목적이 개인자금이면, 연체의 확률은 높아지고 부도의 확률은 낮아진다.

〈표 6〉상환 성공, 연체 및 부도 더미변수에 대한 로짓 회귀분석 결과

이 표는 상환 성공, 연체 및 부도 더미변수를 종속변수로 하고 주요 변수를 설명변수로 하는 로짓 회귀분석에 대한 결과를 보고하고 있다. 대출금액은 차입자가 신청하고 플랫폼에서 확정한 총 대출 금액(천만 원)이여, 대출금리는 대출상품에 대한 연간 투자수익률(\%)이다. 대출기간은 대출상품의 대출만기(년)이고, 신용도는 플랫폼에 제시하는 차입자의 신용등급 정보이다. 사업자금, 차환대출 및 개인자금 더미는 대출목적이 해당 목적인 경우 1 의 값을 갖는 더미변수이다. *, *****는 각각 $10 \%$, $5 \%, 1 \%$ 의 신뢰수준에서 유의적임을 나타낸다.

\begin{tabular}{lccc}
\hline & 상환성공 & 연체 & 부도 \\
\cline { 2 - 4 } & $(3,262$ 건) & $(295$ 건 $)$ & $(163$ 건) \\
\hline 대출금액(천만원) & 0.0430 & -0.0417 & -0.1130 \\
대출금리(\%) & $-0.0791^{* *}$ & $0.1422^{* * *}$ & -0.1047 \\
대출기간(년) & $-0.4643^{* *}$ & $-0.2609^{* *}$ & $1.5683^{* * *}$ \\
신용도(등급) & $0.0805^{*}$ & 0.0091 & $-0.2821^{* * *}$ \\
사업자금 더미 & -0.1590 & 0.5361 & 0.0597 \\
차환대출 더미 & $0.3501^{*}$ & 0.2445 & $-0.8834^{* * *}$ \\
개인자금 더미 & -0.1124 & $0.6860^{* *}$ & $-0.5691^{* *}$ \\
\hline
\end{tabular}

<표 6>은 에잇퍼센트 플랫폼에서도 이러한 투자정보 변수들이 대출의 상환 성공이나 채무불이행에 유의한 영향을 미치고 있음을 보고한다. 이에 모형 1 2의 추정 시에 대출 금액, 대출금리, 대출기간, 신용도, 대출목적 변수를 대출의 상환결과 순위변수에 대한 통제 변수로 사용한다. 하지만 모형 3에서는 투자정보 변수들의 함수로 추정되는 설명변수인 공적 정보 반영 투자자 수가 투자정보 변수들과 높은 상관관계를 가져서 다중공선성 문제가 발생할 수 있다. 이에 모형 3 추정 시에는 이 변수들을 통제변수로 사용하지 않는다.

\section{1 .3 군집행동 여부 및 그 효과 판단}

투자자별 데이터 부재로 인한 자료 제약은 군집행동의 정도를 직접 측정하고 군집행동의 발생 여부를 파악하는 것을 어렵게 한다. 이에 본 연구에서는 이하에서 설명하는 방법론을 사용하여 군집행동의 발생 여부 및 그 효과를 간접적으로 파악하고자 한다. 먼저 공적 정보 반영 투자자 수와 기타 요인 투자자 수가 대출의 채무불이행 정도에 미치는 영향에 대해 다음과 같은 가설들을 설정한다.

가설 1: 공적 정보와 기타 요인을 동시에 반영하는 투자자 수의 증가가 대출의 채무불 
이행 확률을 높이지 않을 것이다.

가설 2: 기타 요인 투자자 수의 증가가 대출의 채무불이행 확률을 높이지 않을 것이다.

가설 3: 공적 정보 반영 투자자 수 증가가 대출의 채무불이행 확률을 높이지 않을 것이다.

가설 1은 가성적(비의도적) 군집행동 가설을 기반으로 한다. 즉, 투자자가 다른 투자자의 투자를 의도적으로 따라 하지 않고 주어진 공적 및 사적 정보를 반영하여 개별적으로 합리적인 투자 결정을 한다. 다만 투자자가 동일한 정보를 기반으로 투자 결정을 하게 됨에 따라 다른 투자자와 동일한 투자 결정을 하는 것처럼 보일 수 있다. 결국 다른 투자자를 추정 하려는 의도성을 갖지 않고 주어진 정보를 반영하여 신용위험에 대한 적절한 평가를 통해 이루어진 투자 결정은 채무불이행의 위험의 증가를 가져오지 않을 것이다. 가설 2 는 투자자가 다른 투자자의 투자를 의도적으로 따라 하지 않고 공적 정보 이외의 요인들을 반영하여 개별적으로 합리적인 투자 결정을 한다는 것을 바탕으로 수립된다. 가설 3 은 차입자의 신용 위험을 평가하는데 필요한 공적 정보가 투자자에게 적절히 제공되고 투자자가 이를 반영 하는 합리적인 의사결정을 한다는 것을 바탕으로 설정된다.

그 다음에는 모형 1 3의 계수의 부호 및 통계적 유의성에 따라 수립한 가설들을 다음과 같이 검증한다.

- 모형 1 에서 투자자 수의 계수가 양(+)의 값을 갖고 유의적이면 가설 1 을 기각한다.

- 모형 2에서 기타 요인 투자자수의 계수가 양 $(+)$ 의 값을 갖고 유의적이면 가설 2 를 기각한다.

- 모형 3 에서 공적 정보 반영 투자자수의 계수가 양 $(+)$ 의 값을 갖고 유의적이면 가설 3 을 기각한다.

마지막으로 가설 1 3의 기각 또는 채택 결과에 따라 다음과 같이 해석한다.

- 가설 1 의 기각은 투자자가 의도성을 갖고 다른 투자자의 투자 결정을 추종하는 군집 행동을 할 가능성을 시사한다.

- 가설 1 및 가설 2의 기각과 가설 3 의 채택은 기타 요인에 의한 투자자수의 증가만이 대출의 채무불이행 위험을 증가시키는 결과로 해석되며, 투자자에게 제공되는 공적 정보 이외의 다른 요인에 의해 투자자가 의도성을 갖고 다른 투자자의 투자 결정을 추종하는 군집행동 가능성을 시사한다.

- 가설 1 과 가설 3 의 기각 및 가설 2 의 채택은 공적 정보에 의한 투자자 수 증가만이 채무불이행 위험 중가를 가져오는 결과로 해석되며, 차입자의 신용위험을 평가하는 데 필요한 공적 정보가 투자자에게 적절히 제공되지 않음을 시사한다.

\section{2 실증분석 결과}

<표 7>은 투자자 수에 대한 회귀분석 결과를 보고하고 있다. 이 표의 두 번째 열은 각 
한국증권학회지 제50권 3호 (2021)

대출의 투자자 수를 직전 모집 투자자 수, 상수항 및 시간 트랜드(Trend)를 설명변수로 하는 회귀식의 추정 결과를 보고하고 있다. 직전 모집 투자자 수의 계수(0.186)가 통계적 으로 유의한 양(+)의 값을 갖는다. 각 대출의 투자자 수가 직전에 모집이 완료된 대출의 투자자 수와 양(+)의 상관관계를 갖는 것은 각 투자상품에 투자하는 투자자들의 의사 결정이 이전 투자상품에 투자한 투자자들의 결정에 영향을 받고 있다는 간접적인 증거로 해석된다.

〈표 7〉투자자 수에 대한 회귀분석 결과

이 표는 투자자 수에 대한 회귀분석 결과를 보고하고 있다. 종속변수인 투자자 수는 대출상품에 참여한 투자자 수(천 명) 값이다. 설명변수로서 대출금액은 차입자가 신청하고 플랫폼에서 확정한 총 대출 금액(천만 원)이여, 대출금리는 대출상품에 대한 연간 투자수익률(\%)이다. 대출기간은 대출상품의 대출만기(년)이고, 신용도는 플랫폼에 제시하는 차입자의 신용등급 정보이다. 사업자금, 차환대출 및 개인자금 더미는 대출목적이 해당 목적인 경우 1 의 값을 갖는 더미변수이다. 거시경제변수는 투자모집이 개시된 해당월의 경제지표로서 실업률은 통계청의 경제활동인구조사 월별 자료(\%)이고, 소비자물가 지수는 2015년 기준의 월별 소비자물가지수(백 포인트)이다. 어음 부도율은 전자결제분이 제외된 어음 부도율 $(\%)$ 이고, 국고채 수익률은 3 년 만기 국고채 수익률(\%)이며, 종합주가지수는 월평균 종합물가지수(천 포인트)이다. F-statistic와 Wald $x^{2}$ 는 모든 회귀계수가 0 이라는 귀무가설에 대한 검정통계량이다. ${ }^{* * *}{ }^{* * *}$ 는 각각 $10 \%, 5 \%, 1 \%$ 의 신뢰수준에서 유의적임을 나타낸다.

\begin{tabular}{lcc}
\hline $\begin{array}{l}\text { 종속변수 } \\
\text { 설명변수 }\end{array}$ & $\begin{array}{c}\text { 투자자 수 } \\
\text { 계수 값 }\end{array}$ & $\begin{array}{c}\text { 투자자 수 } \\
\text { 계수 값 }\end{array}$ \\
\hline 대출금액 & & $0.016^{* * *}$ \\
대출금리 & & $0.009^{* * *}$ \\
대출기간 & & 0.005 \\
신용도 & & $0.027^{* * *}$ \\
사업자금 더미 & & $0.079^{* * *}$ \\
차환대출 더미 & & $0.034^{* * *}$ \\
개인자금 더미 & & $-0.058^{* * *}$ \\
실업률 & & $0.020^{* * *}$ \\
소비자물가지수 & & $2.935^{* * *}$ \\
어음 부도율 & & $-0.558^{* * *}$ \\
국고채 수익률 & & $-0.066^{* * *}$ \\
종합주가지수 & & $0.593^{* * *}$ \\
상수항 & & $-4.236^{* * *}$ \\
직전 모집 투자자 수 & $-309.2^{* * *}$ & \\
Trend & $0.186^{* * *}$ & \\
\hline Adjusted $\mathrm{R}^{2}$ & $0.0004^{* * *}$ & 0.492 \\
F-statistic & 0.264 & $742.4^{* * *}$ \\
Wald $x^{2}$ & $1,525^{* * *}$ & $9,651^{* * *}$ \\
\hline
\end{tabular}

이 표의 세 번째 열은 식 (1)에 대한 추정 결과를 보고하고 있다. 식 (1)은 투자자 수를 플랫폼에서 제공되는 투자정보와 공표되는 거시경제지표와 같은 공적 정보에 의해 설명되는 부분과 그렇지 못한 부분을 분해하기 위한 목적으로 추정된다. 식 (1)에 대한 회귀분석 결과, 플랫폼에서 제공하는 투자정보와 투자시점의 거시경제지표들이 각 대출의 투자자 
Herd Behavior of Investors and Default Risks of P2P Online Lending

수에 상당한 설명력을 갖고 추정 모형의 적합성이 높은 것으로 나타난다. 조정결정계수 (Adjusted $\mathrm{R}^{2}$ )가 $49.2 \%$ 이고, $\mathrm{F}$ 검정 $\left(\mathrm{F}\right.$-statistic) 및 $\mathrm{Wald}$ 검정 $\left(\mathrm{x}^{2}\right)$ 검정 결과 추정 모형의 모든 계수가 0 이라는 귀무가설이 $1 \%$ 유의 수준에서 기각된다.

식 (1)에 대한 추정 결과에 따르면, 각 대출의 투자자 수가 플랫폼에서 제공되는 투자정보와 거시경제변수, 그리고 기타 요인들의 영향을 받아서 결정되는 것으로 나타난다. 각 대출의 투자자 수의 약 $49.2 \%$ 가 투자정보 및 거시경제변수에 의해, 나머지는 기타 요인들에 의해 각각 결정되는 것으로 나타난다. 대출금리와 신용도가 증가하면 투자자 수가 증가하는 것으로 나타 난다. 그리고 대출목적이 사업자금이나 차환대출이면 투자자 수가 증가하고, 개인대출이면 투자자 수가 감소하는 것으로 나타난다. 이러한 투자정보 변수에 대한 추정 결과는 대출 기간을 제외하고 <표 $5>$ 에서 예상한 영향 부호와 일치하는 결과이다. 거시경제지표 중에서 실업률, 소비자물가지수, 종합주가지수는 투자자 수와 양 $(+)$ 의 상관관계를, 어음 부도율, 국고채 수익률은 투자자 수와 음(-)의 상관관계를 갖는 것으로 나타난다. 이러한 거시경제지표 변수에 대한 결과는 투자자들이 투자 결정시점의 경제상황을 거시경제지표를 통해 파악함에 따라 이 변수들이 투자에 참여하는 투자자 수에 영향을 주는 것으로 해석된다.

<표 8>의 두 번째 열과 세 번째 열은 모형 1 2에 대한 순위 프로빗 모형 추정 결과를 보고하고 있다. 각 대출의 상환결과 순위변수를 투자자 수 또는 기타 요인 투자자 수와 채무불이행 영향요인 변수들로 설명하는 식 (2) 및 식 (3)의 추정 모형이 적합한 것으로 나타난다. 모형 1 과 2 의 잔차 분산(error variance)의 감소비율에 해당하는 Pseudo $R^{2}$ 가 $4.5 \%$ 이고, $\mathrm{F}$ 검정 $(\mathrm{F}-$ statistic $)$ 및 Wald 검정 $\left(\mathrm{x}^{2}\right)$ 검정 결과 추정 모형의 모든 계수가 0이라는 귀무가설이 $1 \%$ 유의 수준에서 기각된다.

모형 1 과 모형 2에서 통제변수로 사용된 투자정보 변수에 대한 부호는 대출금액을 제외 하고는 <표 5>의 예측 부호와 유사하게 나타난다. 대출금액이 감소하거나, 대출기간이 증가 하거나 신용도가 낮아지면 채무불이행 확률이 증가한다. 그리고 대출목적이 차환대출이면 채무불이행 확률이 감소한다. 통제변수로 사용된 거시경제지표의 부호는 모형 1 과 모형 2 에서 다르게 나타난다. 모형 1(모형 2)에서는 어음 부도율(종합주가지수) 증가가 채무불이행 확률을 증가시키지만, 다른 거시경제지표 변수들은 채무불이행 확률에 유의한 영향을 주지 못한다. ${ }^{8)}$

모형 1 3의 추정 목적은 설명변수로 추가된 투자자 수와 요인 분해된 투자자 수(공적 정보 반영 투자자 수 또는 기타 요인 투자자 수)가 P2P 대출의 채무불이행 위험에 미치는 영향을 살펴보고 이를 통해 가설 1 3을 검정하기 위함이다. 모형 1 에서 투자자 수의 계수(0.834)는 통계적으로 유의한 양(+)의 값을 갖는다. 이는 공적 정보와 기타 요인을 반영하는 투자자 수의 증가가 채무불이행 위험을 증가시키는 것으로 해석된다. 모형 2에서 기타 요인 투자자 수의 계수(0.834)는 통계적으로 유의한 양(+)의 값을 갖는다. 이는 공적

8) 이는 P2P 대출 플랫폼에서 대출의 투자 시점 기준으로 측정한 거시경제지표가 일정기간이 지난 후에 발생되는 대출의 상환 결과와 다소 괴리가 발생하기 때문일 수 있다. 
한국증권학회지 제50권 3호 (2021)

정보 이외의 기타 요인에 의한 투자자 수의 증가가 채무불이행 위험을 증가시키는 것으로 해석된다. 모형 3에서 기타 요인 투자자 수의 계수(0.605)는 통계적으로 유의한 양(+)의 값을 갖지만, 공적 정보 반영 투자자 수의 계수(-0.687)는 통계적으로 유의한 음(-)의 값을 갖는다. 이는 기타 요인에 의한 투자자 수 증가는 채무불이행 위험을 증가시키지만, 공적 정보를 반영하는 투자자 수의 증가는 채무불이행 위험을 감소시키는 결과로 해석된다.

\section{〈표 8〉채무불이행 정도의 영향요인 분석}

이 표는 채무불이행 정도 결정요인에 대한 순위 프로빗 추정 결과를 보고하고 있다. 종속변수는 대출 상환 성공 $=0$, 연체 $=1$, 부도 $=2$ 의 값을 갖는 채무불이행 확률 순위변수이다. 설명변수로서 대출금액은 차입자가 신청하고 플랫폼에서 확정한 총 대출금액이여, 대출금리는 대출상품에 대한 연간 투자수익률 이다. 대출기간은 대출상품의 대출만기 정보이고, 신용도는 플랫폼에 제시하는 차입자의 신용등급 정보이다. 사업자금, 차환대출 및 개인자금 더미는 대출목적이 해당 목적인 경우 1 의 값을 갖는 더미변 수이다. 거시경제변수는 투자모집이 개시된 해당월의 경제지표로서 실업률은 통계청의 경제활동인구 조사 월별 자료, 소비자물가지수는 2015년 기준의 월별 소비자물가지수이다. 어음부도율은 전자결제분이 제외된 어음 부도율이고, 국고채 수익률은 3 년 만기 국고채 수익률이며, 종합주가지수는 월평균 종합물가지수이다. F-statistic와 Wald $x^{2}$ 는 모든 회귀계수가 0이라는 귀무가설에 대한 검정통계량이다. *,****는 각각 $10 \%, 5 \%, 1 \%$ 의 신뢰수준에서 유의적임을 나타낸다.

\begin{tabular}{|c|c|c|c|}
\hline \multirow{2}{*}{$\begin{array}{l}\text { 종속변수 } \\
\text { 설명변수 }\end{array}$} & \multicolumn{3}{|c|}{ 채무불이행 정도 } \\
\hline & 모형 1 & 모형 2 & 모형 3 \\
\hline 대출금액 & $-0.071^{* *}$ & $-0.057^{* *}$ & \\
\hline 대출금리 & 0.005 & 0.013 & \\
\hline 대출기간 & $0.488^{* * *}$ & $0.492^{* * *}$ & \\
\hline 신용도 & $-0.090^{* * *}$ & $-0.068^{* *}$ & \\
\hline 사업자금 더미 & 0.039 & 0.105 & \\
\hline 차환대출 더미 & $-0.314^{* * *}$ & $-0.286^{* * *}$ & \\
\hline 개인자금 더미 & -0.058 & -0.106 & \\
\hline 실업률 & 0.046 & 0.063 & \\
\hline 소비자물가지수 & -7.212 & -4.765 & \\
\hline 어음 부도율 & $1.013^{* *}$ & 0.548 & \\
\hline 국고채 수익률 & 0.316 & 0.261 & \\
\hline 종합주가지수 & 0.314 & $0.808^{* *}$ & \\
\hline 투자자 수 & $0.834^{* * *}$ & & \\
\hline 기타 요인 투자자 수 & & $0.834^{* * *}$ & $0.605^{* * *}$ \\
\hline 공적 정보 반영 투자자 수 & & & $-0.687^{* * *}$ \\
\hline Pseudo $\mathrm{R}^{2}$ & 0.045 & 0.045 & 0.007 \\
\hline F-statistic & $10.4^{* * *}$ & $10.4^{* * *}$ & $12.0^{* * *}$ \\
\hline Wald $x^{2}$ & $135.4^{* * *}$ & $135.4^{* * *}$ & $24.0^{* * *}$ \\
\hline
\end{tabular}

각 가설에 대한 결과는 가설 1 과 가설 2 의 기각 및 가설 3 의 채택으로 요약된다. 가설 1 의 기각은 통해 차입자와 대출자 간의 정보비대칭 문재가 상존하는 P2P 대출에서 투자자가 다른 투자자를 추종하려는 의도성을 가질 가능성을 시사한다. 가설 2 의 기각은 투자자에게 
Herd Behavior of Investors and Default Risks of P2P Online Lending

제공되는 공적 정보 이외의 요인으로 인하여 군집행동이 발생할 수 있음을 시사한다. 가설 3 의 채택은 차입자의 신용위험을 평가하는데 필요한 공적 정보가 투자자에게 적절히 제공 되고 있고 공적 정보 요인으로 인한 투자자의 군집행동이 발생하지 않음을 시사한다.

이상의 분석 결과를 종합하면, 투자자에게 제공되는 공적 정보 이외의 다른 요인에 의해 투자자가 의도성을 갖고 다른 투자자의 투자 결정을 추종하는 군집행동의 가능성을 시사 한다. 또한 이러한 결과는 현재 플랫폼에서 제공되는 투자정보 이외에 차입자의 신용위험을 판단하는데 도움이 되는 추가적인 정보를 투자자에게 제공함으로써 군집행동을 줄일 수 있음을 시사한다.

\section{5. 결론 및 시사점}

에잇퍼센트는 다수의 투자자가 잠재적인 차입자가 신청한 대출상품에 투자를 하는 가격 게시형 P2P 온라인 대출 플랫폼이다. 이 플랫폼은 투자자에게 차입자의 대출신청금액, 대출 금리, 대출기간, 신용등급 등의 투자정보와 차입자의 인구통계정보를 제공한다. $\mathrm{P} 2 \mathrm{P}$ 대출이 정보비대칭이 존재하는 온라인 환경에서 이루어지기 때문에 대출상품의 신용위험 평가에 상당한 불확실성이 존재한다. 이러한 불확실성과 $\mathrm{P} 2 \mathrm{P}$ 대출의 특성으로 인해 투자자의 군집 행동이 나타날 수 있다.

이에 본 연구에서는 에잇퍼센트의 대출 자료를 이용하여, $\mathrm{P} 2 \mathrm{P}$ 대출시장에서 투자자의 군집행동이 대출의 채무불이행 위험에 미치는 영향을 분석한다. 그리고 이러한 분석을 통해 간접적으로 투자자의 군집행동의 발생 여부와 그 효과를 규명한다. 본 연구의 주요 결과는 다음과 같다. 첫째, 각 대출의 투자자 수는 플랫폼이 투자자에게 제공하는 투자정보와 공표 되는 거시경제지표 등 공적 정보를 반영한다. 둘째, 플랫폼에서 제공되는 공적 정보를 제외한 기타 요인에 의한 투자자 수의 증가는 대출의 채무불이행 위험을 증가시키지만, 공적 정보를 반영하는 투자자 수는 채무불이행 위험을 감소시킨다. 이러한 결과는 가격 게시형 P2P 대출 플랫폼에서 공적 정보를 제외한 요인으로 인해 투자자의 군집행동이 발생할 수 있으며, 이러한 군집행동은 플랫폼을 통해 제공되는 공적 정보 양의 증가 및 질의 개선을 통해 축소될 수 있음을 시사한다.

$\mathrm{P} 2 \mathrm{P}$ 대출에서 투자자는 투자자와 차입자 간의 정보비대칭 문제의 완화를 위해 플랫폼이 제공하는 공적 정보를 바탕으로 투자 결정을 한다. 플랫폼에 의해 제공되는 공적 정보가 부족하면, 투자자가 다른 투자자들의 투자 결정으로부터 정보를 얻고자 하는 정보 폭포 (information cascade) $)^{9)}$ 군집행동이 나타날 수 있다. 정보 폭포에 의한 군집행동이 발생

9) Banerjee(1992), Bikhchandani et al.(1992) 등은 정보 폭포에 의한 군집행동에 대한 이론 모형을 제시한다. 정보 폭포는 정보의 불완전성과 사적 정보가 존재하는 상황에서 동일한 선택 문제에 직면한 개별 주체들이 앞서 선택한 다른 구성원들의 선택을 통해 그들의 사적 정보를 유추하게 되며, 만약 특정 선택을 한 수가 그 선택을 하지 않은 수보다 많으면 뒤에 선택하는 구성원들은 
하면 개별 투자자는 최선의 합리적인 의사결정을 했으나 투자자 전체적으로는 바람직하지 못한 선택을 하는 역선택(adverse selection)의 문제 발생 가능성이 있다. 또한 플랫폼에 의해 제공되는 공적 정보가 부족하면, 지식과 경험 부족으로 차입자의 신용도를 평가할 능력이 없는 투자자가 비합리적으로 다른 투자자의 결정을 추종할 수 있다. 투자자가 투자 결정을 내려야 할 때, 투자자 자신의 지식과 투자정보 분석, 그리고 다른 투자자들이 내린 결정의 관찰 두 가지를 통해 정보를 얻는다. $\mathrm{P} 2 \mathrm{P}$ 대출에서 자신의 지식과 투자정보 분석 결과에 확신이 없는 투자자라면 다른 투자자들이 내린 결정에 더 의존하려는 경향을 가질 것이기 때문이다.

본 연구의 결과는 현재 국내 $\mathrm{P} 2 \mathrm{P}$ 대출 플랫폼에서 제공하는 투자정보의 보완이 필요하다는 정책적 시사점을 제공한다. 세계 최대의 $\mathrm{P} 2 \mathrm{P}$ 대출 플랫폼인 미국 랜딩클럽에서는 금융정보 (DTI, 금융거래 내용), 신용정보(파산, 연체정보, 신용한도), 재무정보, 주거정보(보유, 모기지) 등 차입자의 상세한 투자정보를 제공한다. 국내 $\mathrm{P} 2 \mathrm{P}$ 대출 플랫폼에서도 랜딩클럽과 같이 투자자에게 차입자에 대한 상세한 투자정보 제공을 함으로써 차입자와 정보격차를 줄이고 $\mathrm{P} 2 \mathrm{P}$ 대출시장의 효율성을 향상시킬 수 있을 것이다.

투자자의 군집행동과 $\mathrm{P} 2 \mathrm{P}$ 대출의 채무불이행 위험에 대한 심도 있는 이해를 위해 다음 사항에 대한 후속 연구가 이루어지기를 기대해본다. 첫째, 경매형 플랫폼과 가격 게시형 플랫폼의 동시 분석을 고려해볼 수 있다. 두 유형의 플랫폼을 동시에 분석하면, 두 유형 플랫폼의 실증분석 결과의 비교가 가능하기 때문이다. 둘째, 투자자 수에 대한 다중 회귀 분석에서 차입자가 플랫폼에서 공개한 인구통계학적 정보를 이용하여 개별 대출의 특성 변수들을 통제하는 것을 고려할 수 있다. 본 연구에서는 에잇퍼센트 플랫폼이 차입자의 인구통계학적 정보 등 연성 정보(soft information)를 공개하지 않아, 이러한 자료의 획득 및 분석이 이루어지지 않았으나, 이러한 분석이 이루어진다면, 분석 방법론의 향상을 기여할 것으로 기대된다.

자신의 사적 정보를 무시하고 보다 많은 구성원들의 선택을 모방하는 과정에서 발생하는 군집행동을 지칭한다. 
Herd Behavior of Investors and Default Risks of P2P Online Lending

\section{References}

Banerjee, A. V., 1992, A Simple Model of Herd Behavior, American Economic Review, Vol. 88, pp. 724-748.

Bikhchandani, S. and S. Sharma, Herd Behavior in Financial Markets: A Review, IMF Working Paper 00/48, IMF Institute, 2000, https://www.imf.org/External/Pubs/FT/staffp/2001/01 /pdf/Bikhchan.pdf.

Bikhchandani, S., D. Hirshleifer, and I. Welch, 1992, A Theory of Fads, Fashion, Custom and Cultural Change as Informational Cascades, Journal of Political Economy, Vol. 100, pp. 992-1026.

Bruton, G., S. Khavul, D. Siegel, and M. Wright, 2014, New Financial Alternatives in Seeding Entrepreneurship: Micro Finance, Crowdfunding and Peer-to-Peer Innovations, Entrepreneurship Theory and Practice, Vol. 39 (1), pp. 9-26.

Carmichael, D., Modeling Default for Peer-to-Peer Loans, Working Paper, University of Houston, 2014, https://papers.ssrn.com/sol3/papers.cfm?abstract_id=2529240.

Emekter, R., Y. Tu, B. Jirasakuldech, and M. Lu, 2015, Evaluating Credit Risk and Loan Performance in Online Peer-to-Peer(P2P) Lending, Applied Economics, Vol. 47 (1), pp. 54-70.

Feng, Y., X. Fan, and Y. Yoon, 2015, Lenders and Borrowers' Strategies in Online Peer-toPeer Lending Market: An Empirical Analysis of PPDai.com, Journal of Electronic Commerce Research, Vol. 16 (3), pp. 242-260.

Freedman, S., and G. Z. Jin, Do Social Networks Solve Information Problems for Peer-toPeer Lending? Evidence from Prosper.com, Working Paper, Net Institute, 2008, https://econpapers.repec.org/paper/netwpaper/0843.htm.

Herzenstein, M., U. M. Dholakia, and R. Andrews, 2011, Strategic Herding Behavior in Peer-to-Peer Loan Auctions, Journal of Interactive Marketing, Vol. 25 (1), pp. 27-36.

Iyer, R., A. I. Khwaja, E. F. Luttmer, and K. Shue, 2015, Screening Peers Softly: Inferring the Quality of Small Borrowers, Management Science, Vol. 62 (6), pp. 1554-1577.

Jagtiani, J., and C. Lemieux, Fintech Lending: Financial Inclusion, Risk Pricing, and Alternative Information, Working paper, Federal Reserve Bank of Philadelphia, 2017, https://www.fdic.gov/analysis/cfr/bank-research-conference/annual-17th/papers/14 -jagtiani.pdf.

Kim, H. K., and K. W. Park, 2013, A Study on the Determinants of The Characteristics of Online Peer-to-Peer Lending, Journal of the Korean Operations Research and Man- 
agement Science Society, Vol. 38 (4), pp. 79-94.

Kim, H. K., K. W. Park, B. T. Lee, and E. H. Choi, 2013, A Study on Determinants of Loan Repayment in Peer-to-Peer Lending, Asian Review of Financial Research, Vol. 26 (3), pp. 381-415.

Lee, E., and B. Lee, 2012, Herding Behavior in Online P2P Lending: An Empirical Investigation, Electronic Commerce Research and Applications, Vol. 11 (5), pp. 495-503.

Mach, T., C. Carter, and C. Slattery, Peer-to-Peer Lending to Small Businesses, Finance and Economics Discussion Series 2014-10, Board of Governors of the Federal Reserve System (U.S.), 2014, http://www.federalreserve.gov/pubs/feds/2014/201410/2 01410pap.pdf.

Nowak, A., A. Ross, and C. Yencha, 2018, Small Business Borrowing and Peer-to-Peer Lending: Evidence from Lending Club, Contemporary Economic Policy, Vol. 36 (2), pp. 318-336.

Polena, M., and T. Regner, 2018, Determinants of Borrowers' Default in P2P Lending under Consideration of the Loan Risk Class, Games, Vol. 9 (4), pp. 1-17.

Serrano-Cinca, C., B. Gutierrez-Nieto, and L. López-Palacios, 2015, Determinants of Default in P2P Lending, PLOS ONE, Vol. 10 (10), pp. 1-22.

Shin, D. H., and M. S. Chae, 2012, An Empirical Study on the Default Factor in Online P2P Lending, Korean Journal of Business Administration, Vol. 25 (5), pp. 2233-2254.

WEF, 2015, The Future of FinTech: A Paradigm Shift in Small Business Finance, Global Agenda Council on the Future of Financing \& Capital, World Economic Forum, http:// www3.weforum.org/docs/IP/2015/FS/GAC15_The_Future_of_FinTech_Paradigm_Shif t_Small_Business_Finance_report_2015.pdf.

Wei, Z., and M. Lin, 2016, Market Mechanisms in Online Peer-to-Peer Lending, Management Science, Vol. 63 (12), pp. 4236-4257

Wen, X., Z. Zhang, and X. Wu, 2017, A Research on the Influence Factors of P2P Lending Market, Advances in Economics and Business, Vol. 5 (1), pp. 11-17.

Zhang, J., and P. Liu, 2012, Rational Herding in Microloan Markets, Management Science, Vol. 58 (5), pp. 892-912.

Zhang, K., and X. Chen, 2017, Herding in a P2P Lending Market: Rational Inference or Irrational Trust?, Electronic Commerce Research and Applications, Vol. 23, pp. 45-53. 